\title{
Pelaksanaan Pemeriksaan Terhadap Pelaku Penyalahguna Narkotika Dengan Sistem Rehabilitasi di Badan Nasional Narkotika Propinsi Jawa Tengah.
}

\author{
Andri Winjaya Laksana \\ Dosen Fakultas Hukum UNISSULA \\ andriwinjaya@gmail.com
}

\begin{abstract}
Human Trafficking especially against women and children is a crime whose perpetrators must be severely punished. Most victims of trafficking are women and children whose educational level is low and the weak economic situation, therefore victims should receive legal protection. The method used in this research is juridical sociological or socio legal research, the method or procedure used to solve research problems by examining secondary data such as ingredients laws or regulations applicable law followed by conducting research on the data primer on the field. The results showed, 1) factors that cause human trafficking are poverty, low education, Promiscuity, lack of information. 2) obstacles in the legal protection for trafficking victims even though the government has issued Law No. 21 of 2007 on the Eradication of Trafficking in Persons, but it is unfortunate that the law can not be enforced effectively, because there are some obstacles in the form factor of non-juridical include economic factors, poverty, education factors are low and social and cultural factors.
\end{abstract}

Keywords: legal protection, woman dan children, victims of human trafficking

\begin{abstract}
Abstrak
Perdagangan orang (trafficking) terutama terhadap perempuan dan anak merupakan kejahatan yang pelakunya harus dihukum berat. Kebanyakan korban trafficking adalah perempuan dan anak yang tingkat pendidikannya rendah dan keadaan ekonominya lemah, oleh karena itu korban perlu mendapatkan perlindungan hukum. Metode pendekatan yang digunakan dalam penelitian ini adalah pendekatan yuridis sosiologis atau socio legal research, yaitu cara atau prosedur yang digunakan untuk memecahkan masalah penelitian dengan meneliti data sekunder yang berupa bahan-bahan hukum atau peraturan-peraturan hukum yang berlaku kemudian dilanjutkan dengan mengadakan penelitian terhadap data primer di lapangan. Hasil penelitian menunjukan, 1) faktor yang menjadi penyebab terjadinya perdagangan manusia yaitu Kemiskinan, Rendahnya Pendidikan, Pergaulan bebas, Kurangnya Informasi. 2) kendala dalam perlindungan hukum terhadap korban kejahatan perdagangan orang meskipun pemerintah telah mengeluarkan UU No. 21 Tahun 2007 tentang Pemberantasan Tindak Pidana Perdagangan Orang namun sangat disayangkan bahwa undang-undang tersebut belum dapat diberlakukan secara efektif, karena adanya beberapa kendala yaitu berupa faktor non-yuridis yang meliputi faktor ekonomi, faktor kemiskinan, faktor pendidikan yang rendah serta faktor sosial dan budaya.
\end{abstract}

Kata kunci: Perlindungan Hukum, Perempuan dan Anak, Korban Perdagangan Manusia. 


\section{A. PENDAHULUAN}

Remaja adalah generasi yang berpengaruh dalam mewujudkan cita cita suatu bangsa, sebagai generasi penerus dan sebagai generasi yang diharapkan oleh suatu bangsa bisa merubah keadaan bangsanya yang lebih baik. Tumbuh kembang remaja pada zaman sekarang sudah tidak bisa lagi di banggakan dan diteladani. Perilaku kenakalan remaja saat ini sulit diawasi dan diatasi. Baru-baru ini sering kita dengar berita diberbagai media massa maupun di media cetak tentang kenakalan remaja yang antara lain tawuran, pemerkosaan, hingga kenakalan menggunakan narkotika dan psikotropika secara sembarangan. Penyalahgunaan narkotika dan psikotropika saat ini tidak hanya melibatkan pelajar SMU dan Mahasiswa tetapi telah merabah pelajar setingkat SD. ${ }^{1}$ Rusaknya moral para remaja dipengaruhi oleh beberapa perubahan moral remaja yaitu pergaulan bebas.

Perilaku kenakalan remaja inilah yang menimbulkan sifat yang cenderung lebih agresif, emosi tidak stabil, dan tidak bisa menahan dorongan nafsu. Awal mula penggunaan narkotika oleh remaja ini adalah coba-coba, tapi dari coba-coba inilah adalah awal masalah yang membuat mereka ketergantungan dan tidak mengerti akan bahayanya. Budaya ini pula yang menyebabkan ia dapat mengubah kualitas lingkungan hidupnya dengan segala konsekuensinya. $^{2}$

Narkotika merupakan zat atau obat yang sangat bermanfaat dan diperlukan untuk pengobatan penyakit tertentu. Namun jika disalahgunakan atau digunakan tidak sesuai dengan standar pengobatan dapat menimbulkan akibat yang sangat merugikan bagi perorangan atau masyarakat khususnya generasi muda. Hal ini akan lebih merugikan jika, disertai dengan penyalahgunaan dan perdaran gelap narkotika yang dapat mengakibatkan bahaya yang lebih besar

1 H.M.Ra'uf.2002,Dampak Penyalahgunaan Narkoba Trhadap Remaja dan Kamtibmas,Dharma Bhakti,Jakarta. hlm 1

2 Juli Suemirat Slamet, 1994,Kesehatan Lingkungan,Gagjah Mada University Press, Jogyakarta.hIm 21 bagi kehidupan dan nilai-nilai budaya bangsa yang pada akhirnya akan dapat melemahkan ketahanan nasional. ${ }^{3}$

Penyalahgunaan Narkotika telah meluas disebagian kalangan masyarakat di kota-kota besar maupun kota-kota kecil bahkan peredaran sulit dihentikan. Penyalahgunaan narkotika digunakan tidak untuk tujuan mengobati penyakit, akan tetapi digunakan dengan sengaja untuk mencapai "kesadaran tertentu" karena pengaruh obat pada jiwa. Sebagai masyarakat Indonesia yang pada umumnya saat ini sedang dihadapkan pada keadaan yang sangat susah mengkhawatirkan akibat maraknya pemakaian, secara sembarangan macammavam narkotika maupun psikotropika.

Pada dasarnya peredaran narkotika di Indonesia sudah sangat luas. Undangundang No. 35 Tahun 2009 Tentang Narkotika telah memberi perlakuan yang berbeda bagi pelaku penyalahgunaan narkotika. Pengguna atau pecandu narkotika sebagai pelaku tindak pidana narkotika adalah dengan pidana penjara yang diberikan pada para pelaku penyalahgunaan narkotika. Disamping itu dapat dikatakan pecandu narkotika tersebut merupakan korban adalah ditunjukan dengan adanya ketentuan bahwa terhadap pecandu narkotika dapat dijatuhi vonis rehabilitasi.

Penegakan hukum terhadap kejahatan di Indonesia, khusus dalam pemidanaan, seharusnya merujuk pada pendekatan norma yang bersifat menghukum penjahat sehingga dapat membuat efek jera. Eksistensi penegakan hukum dalam hal visi dan misipenegakan hukumnya, baik di tingkat penyidik, penuntut sampai tingkat pengadilan, harusnya memiliki presensi yang sama sesuai tuntutan hukum dan keadilan masyarakat. ${ }^{4}$ Pada kenyataannya eksistensi aparat penegak hukum tersebut terdapat kecenderungan atau terkesan membela pelaku kejahatan dan kurang memperlihatkan banyaknya korban yang

3 Kaka Alvian Nasution, 2014, Himpunan Lengkap Undang-Undang Narkotika dan Psikotropika, Saufa, Jogyakarta.hlm 154

4 Siswanto Sunarsono, 2004, Penegakan Hukum Psikotropika Dalam Kajian Sosiologi Hukum, Grafindo, Jakarta.hIm 7. 
telah berjatuhan sebagai efek ketergantungan narkotika.

Efek yang diakibatkan oleh narkotika ini sangat dirasakan besar pengaruhnya terhadap pribadi maupun masyarakat. Efek dari akibat pengguna natkotika bagi pribadi yaitu menyebabkan penurunan atau perubahan kesadaran, menghilangkan sampai mengurangi rasa nyeri, dan menimbulkan ketergantungan bagi diri sendiri. Sedangkan efek dampak kerugian bagi masyarakat yaitu menyebabkan kecelakaan, menimbulkan tindak kejahatan/kriminal, dan gangguan lain terhadap masyarakat.

Penyalahgunaan narkotika dan akibatnya, baik terhadap penyalahguna atau pemakai yang dikatagorikan pecandu maupiuh akibat-akibat sosialnya, telah lama menjadi masalah serius diberbagai negara yang akhir-akhir ini cenderung kearah yang sangat membahayakan, dimana pemakai akan ketergantungan dan hidupnya akan ketergantunagn oleh zat-zat narkotika.

Sedemikian kompleksnya menahan penyalahgunaan yang di duga sebagai pecandu agar bertahan hanya dalam kurun waktu minimal ternyta bukanlah perkara yang mudah. Selanjutnya, dibutuhkan waktu dan strategi juga guna memaksa individu agar tetap terlibat aktif dalam proses intervensi hingga ia menunjukan tanda-tanda kesembuhan yang cukup meyakinkan. ${ }^{5}$

Rehabilitasi adalah upaya memulihkan dan mengembalikan kondisi para mantan penyalahguna/ketegantungan NAZA kembali sehat dalam arti sehat fisik, psikologik, sosial dan spiritual/agama (keimanan). Dengan konsisi sehat tersebut diharapkan mereka akan mampu kembali berfungsi secara wajar dalam kehidupannya sehati-hari bauik di rumah, di sekolah/kampus, di tempat kerja dan di lingkungan sosialnya. ${ }^{6}$

Dalam Undang-undang No.35 Tahun 2009 Tentang Narkotika diatur tentang

5 Reza Indragiri, 2008, Psikologi Kaum Pengguna Narkoba, Salemba Humanika, Jakarta.hlm 80.

6 Dadang Hawari, Psikiater, 2006, Penyalahgunaan \& Ketergantungan NAZA (Narkotika, Alkohol, \& Zat Adiktif), Gaya Baru, Jakarta, hlm.132. pengobatan dan rehabilitasi. pecandu dan korban penyalahgunaan narkotika tidak lagi diberikan kebebasan untuk sembuh, karena sudah ada ketentuan yang mengaturnya dengan kesadarans sendiri atau keluarganya untuk melaporkan dan atau merehabilitasi para pelaku penyalahguna yang kecanduan. Melakukan rehabilitasi bagi para penyalahguna narkotika adalah untuk menempatkan para pengguna narkotika baik yang bersalah maupun tidak bersalah menjalani dan atau perawatan melalui rehabilitasi. Hakim selaku penegak hukum juga diberi wewenang untuk menjatuhkan putusan pada penyalahguna yang tidak bersalah melakukan tindak pidana narkotika untuk tetap menjalani pengobatan dan rehabilitasi.

Undang-undang No. 35 Tahun 2009 tentang Narkotika juga memuat pasal 54 yang mengatur tentang rehabilitasi. Pasal 54 yang berbunyi "Pecandu narkotika dan korban penyalahgunaan Narkotika wajib menjalani rehabilitasi medis dan rehabilitasi sosial. ${ }^{7}$ Rehabilitasi medis adalah suatu proses kegiatan pengobatan secara terpadu untuk membebaskan pecandu dari ketergantungan narkotika. Reahabilitasi medis pecandu narkotika dapat dilakukan di rumah sakit yang ditunjuk oleh menteri kesehatan yaitu rumah sakit yang diselenggarakan baik oleh pemerintah, maupun oleh masyarakat. Selain pengobatan atau perawatan melalui rehabilitasi medis, proses penyembuhan pecandu narkotika dapat diselenggarakan oleh masyarakat melalui pendekatan keagamaan dan tradisional. Sedangkan rehabilitasi sosial adalah suatu proses kegiatan pemulihan secara terpadu baik secara fisik, mental maupun sosial agar bekas pecandu narkotika dapat segera kembali melakukan fungsi sosial dalam melakukan kehidupan masyarakat. Yang dimaksud bekas pecandu narkotika disini adalah orang yang telah sembuh dari ketergantungan terhadap narkotika secara fisik dan psikis. Atas dasar uraian tersebut diatas maka dirumuskanlah masalah sebagai berikut:

7 Undang-undang No.35 Tahun 2009 Tentang Narkotika 
1. Faktor-faktor apa saja yang melatarbelakangi terjadinya kasus human trafficking?

2. Faktor-faktor Yang Menjadi Kendala Dalam perlindungan hukum korban human trafficking?

\section{B. METODE PENELITIAN}

Metode pendekatan yang digunakan dalam penelitian ini adalah pendekatan yuridis sosiologis atau socio legal research, yaitu cara atau prosedur yang digunakan untuk memecahkan masalah penelitian dengan meneliti data sekunder yang berupa bahan-bahan hukum atau peraturan-peraturan hukum yang berlaku kemudian dilanjutkan dengan mengadakan penelitian terhadap data primer di lapangan. Penelitian ini dimaksudkan dengan penelitian untuk menemukan in concreto, ${ }^{8}$ yakni perlindungan hukum terhadap korban kejahatan perdagangan orang.

C. HASIL PENELITIAN DAN PEMBAHASAN 1. Faktor-Faktor Apa Saja Yang Melatarbelakangi Terjadinya Kasus Perdagangan Terhadap Perempuan Dan Anak

Dasar pemeriksaan terhadap korban penyalahgunaan narkotika adalah pada Undang Undang No. 35 Tahun 2009 Tentang Narkotika yaitu dengan cara rehabilitasi. ${ }^{9}$ Rehabilitasi yang diatur dalam pasal 54 yang berbunyi "pecandu narkotika dan korban penyalahgunaan narkotika wajib menjalani rehabilitasi medis dan rehabilitasi sosial"10. Dalam Undang Undang No. 35 Tahun 2009 Tentang Narkotika instansi yang berwenang melakukan proses rehabilitasi adalah BNN (Badan Narkotika Nasional) yang sudah diatur dalam pasal 70 sampai pasal 72 meiliki tugas dan wewenang

8 Ronny Hanintijo Soemitro, 1990, Metode Penelitian Hukum dan Jurimetri, Ghalia Indonesia, Jakarta, hlm.12.

9 Wawancara dengan Kepala Bidang Pencegahan dan Pemberdayaan Masyarakat Bapak SusantO, S.H.,M.H tanggal 12 Juni 2016

10 Undang-Undang No. 35 Tahun 2009 Tentang Narkotika sebagai berikut :

Pasal 70:

"BNN mempunyai tugas :

1. Menyusun dan melaksanakan kebijakan nasional mengenai pemcegahan dan pemberantasan penyalahgunaan dan peredaran gelap Narkotika dan Prekursor Narkotika:

2. Mencegah dan memberantas penyalahgunaan dan peredaran gelap Narkotika dan Prekursor Narkotika;

3. Berkoordinasi dengan Kepala kepolisisan Negara Republik Indonesia dalam pencegahan dan pemberantasan penyalahgunaan dan peredaran gelap Narkotika dan Prekursor Narkotika;

4. Meningkatkan kemampuan lembaga rehabilitasi medis dan rehabilitasi sosial pecandu Narkotika, baik yang diselenggarakan oleh pemerintah maupun masyarakat.

5. Memberdayakan masyarakat dalam rangka pencegahan, penyalahgunaan dan peredaran gelap Narkotika dan Prekursor Narkotika;

6. Memantau, mengarahkan, dan meningkatkan kegiatan masyarakat dalam pencegahan penyalahgunaan dan dan peredaran gelap Narkotika dan Prekursor Narkotika;

7. Melakukan Kerjasama bilateral dan multirateral baik regional maupun internasional, guna mencegah dan memberantas peredaran gelap Narkotika dan Prekursor Narkotika.

8. Mengembangkan laboratorium Narkotika dan prekursor Narkotika;

9. Melaksanakan administrasi 
penyelidikan dan penyidikan

terhadap perkara

penyalahgunaan dan peredaran

gelap Narkotika dan Prekursor

Narkotika.

10. membuat laporan tahanan mengenai pelasanaan tugas dan wewenang."

Pasal 71

"Dalam melaksanakan tugas pemberantasan penyalahgunaan dan perdaran gelap Narkotika dan Prekursor Narkotika,BNN berwenang melakukan penyelidikan dan penyidikan penyalahgunaan dan peredaran gelap Narkotika dan Prekursor Narkotika."

Pasal 72

"BNN mempunyai Wewenang:

1. Kewenangan sebagaimana dimaksud dalam pasal 71 dilaksanakan oleh penyidik BNN

2. Penyidik BNN sebagaimana dimaksud pada ayat (1) diangkat dan diberhentikan oleh Kepala BNN

3. Ketentuan lebih lanjut mengeni syarat dan tatacara pengangkatan dan pemberhentian penyidik BNN sebagaimana dimaksud pada ayat (2) diatur dengan peraturan kepala BNN."11

Pemeriksaan dan penangkapan korban maupun pelaku penyalahgunaan narkotika yang dilakukan oleh BNN akan diadili oleh hakim yang ditujuk. Tugas dan wewenang hakim ini sudah tercantum pasal 103 Undang-Undang No. 35 Tahun 2009 Tentang Narkotika adalah sebagai berikut: ${ }^{12}$

1. Hakim yang memeriksa perkara pecandu narkotika dapat :

a. Memutus untuk memerintah yang bersangkutan menjalani pengobatan dan atau perawatan melalui rehabilitasi jika pecandu narkotika tersebut terbukti

11 Ibid

12 Wawancara dengan Staff Bagian TU pencegahan dan pemberdayaan masyarakat Bapak Samsul Maakarif bersalah melakukan tindak pidana narkotika atau

b. Menetapkan untuk memerintah yang bersangkutan menjalani pengobatan dana tau perawatan melalui rehabilitasi jika pecandu narkotika tersebut tidak terbukti bersalah melakukan tindak pidana narkotika.

2. Masa menjalani pengobatan dan atau perawatan bagi pecandu narkotika sebagaimana dimaksud pada ayat (1) huruf a di perthitungkan sebagai masa menjalani hukuman."

Penyampaian hukuman yang diputus oleh hakim tentang perkara penyalahgunaan narkotika juga wajib memeperhatikan ketentuan yang berlaku. Ketentuan yang berlaku ini sudah diatur dalam pasal 127 adalah

1. Setiap penyalahguna :

a. Narkotika Golongan I bagi diri sendiri dipidana dengan pidana penjara paling lama 4 (empat) tahun ;

b. Narkotika golongan II bagi diri sendiri dipidana dengan pidaan penjara paling lama 1 (satu) tahun

c. Narkotika golongan III bagi diri sendiri dipidana dengan pidana penjara paling lama 1 (satu) tahun.

2. Dalam memutus perkara sebagaimana dimaksud pada ayat (1), hakim wajib memperhatikan ketentuan sebagaimana dimaksud dalam pasal 54, pasal 55, Pasal 103.

3. Dalam penyalahgunaan sebagaimana dimaksud pada ayat (1) dapat dibuktikan atau terbukti sebagai korban penyalahgunaan narkotika, penyalahgunaan tersebut wajib menjalani rehabilitasi medis dan rehabilitasi sosial. Penyalahgunaan narkotika pada akhir ini dirasakan semakin meningkat. Dapat kita amati dari pemberitaan-pemberitaan baik di media cetak maupun elektronika yang hampir setiap hari memberitakan tentang penangkapan para pelaku penyalahgunaan narkoba oleh aparat 
penegak hukum. Pelaku penyalahgunaan narkotika yang semakin meningkat sangat mengkhawatirkan bagi semua masyarakat. Penyalahgunaan narkotika baik sebagai korban penyalahgunaan narkotika maupun sebagai pelaku penyalahgunaan narkotika. Korban penyalahguna inilah yang harus lebih diperhatikan, karena untuk melakukan rehabilitasi juga harus mendapat perhatian penuh dari semua pihak, tetapi dalam upaya pengobatan dan perawatan yang dilakukan belum optimal dan terpadu. ${ }^{13}$

Peningkatan tersebutlah yang menjadi bahan pertimbangan bagi Mahkamah Agung beserta aparat penegak hukum lainnya untuk membuat PERBER (Peraturan Bersama) No. 01 Tahun 2014 Tentang Penanganan Pecandu Narkotika dan Korban Penyalahguna Narkotika ke dalam Lembaga Rehabilitasi. Arti PERBER No. 01 Tahun 2014 Tentang Penanganan Pecandu Narkotika dan Korban Penyalahguna Narkotika ke dalam Lembaga Rehabilitasi sudah diatur dalam Pasal 1 adalah sebagai berikut :

1. Pecandu Narkotika adalah orang yang menggunakan atau menyalahgunakan narkotika dan dalam keadaan ketergantungan para narkotika, baik secara fisik maupun psikis.

2. Penyalahguna adalah orang yang menggunakan narkotika tanpa hak atau melawan hukum.

3. Korban penyalahguna narkotika adalah seseorang yang tidak sengaja menggunakan narkotika karena dibujuk, diperdaya, ditipu, dipaksa dan atau diancam untuk mrnggunakan narkotika.

4. Ketergantungan narkotika adalah kondisi yang ditandai oleh dorongan untuk menggunakan narkotika terus menerus dengan takaran yang meningkat agar menghasilkan efek yang sama dan apabila penggunanyadikurangi dan atau dihentikan secara tiba-tiba, menimbulkan gejalafisik dan psikis yang khas.

13 Wawancara dengan Kepala Bidang Pencegahan dan Pemberdayaan Masyarakat Bapak Samsul Maakarif tanggal 12 juni 2016
5. Narkotika pemakaian Satu Hari adalah narkotika jumlah tertentu yang dibawa, dimiliki, disimpan, dan dikuasai untuk digunakan oleh penyalahguna narkotika.

6. Tim Asesmen Terpadu adalah tim yang terdiri dari Tim Dokter dan Tim Hukum yang ditetapkan oleh pimpinan satuan kerja setempat berdasarkan surat keputusan Kepala Badan Narkotika Nasional, Badan Narkotika Nasional Provinsi, Badan Narkotika Nasional Kab/Kota.

7. Rehabilitasi medis adalah suatu proses kegiatan pengobatan secara terpadu untuk membebaskan pecandu dari ketergantungan narkotika.

8. Rehabilitasi Sosial adalah suatu proses kegiatan pemulihan secara terpadu, baik fisik, mental maupun sosial, agar bekas pecandu narkotika dapat kembali melaksanakan fungsi sosial dalam kehidupan bermasyarakat.

9. Lembaga rehabilitasi medis adalah fasilitas pelayanan kesehatan yang melaksanakan rehabilitasi medis bagi pecandu, korban penyalahgunaan dan penyalahguna narkotika yang dikelola oleh pemerintah.

10. Lembaga rehabilitasi sosial adalah tempat atau panti yang melaksanakan rehabilitasi sosial bagi pecandu, korban penyalahguna dan penyalahguna narkotika yang dikelola oleh pemerintah.

11. Lembaga pemasyarakatan yang selanjutnya disebut LAPAS adalah tempat untuk melaksanakan pembinaan narapidana dan Anak Didik Pemasyarakatan.

12. Rumah Tahanan Negara yang selanjutnya disebut RUTAN adalah tempat tersangka atau terdakwa selama proses penyidik, penuntun dan pemeriksaan disidang pengadilan.

13. Komplikasi medis adalah gangguan fisik atau penyakit serius terkait kondisiAIDS, Hepatitis, penyakit infeksi dan penyakit non infeksi lainnya seperti kanker, diabetes melitus.

14. Komplikasi Psikiatris adalah gangguan psikiatris atau jiwa dalam hal pasien 
mengalami halusinasi, waham, kecemasandan depresi serius.

Dalam melaksanakan PERBER No 01 Tahun 2014 agar mewujudkan koordinasi dan kerjasama secara optimal dalam penyelesaian permasalahan narkotika serta dapat menurunkan jumlah pelaku penyalahguna maupun korban penyalahguna melalui program rehabilitasi, maka didalam PERBER No 01 Tahun 2014 terdapat penjelasan mengenai Team Asesmen Terpadu. ${ }^{14}$ Team Assesmen Terpadu ini terdapat dalam pasal 8 sampai pasal 10 yaitu sebagai berikut:

Pasal 8

1. Dalam melaksanakan Asesmen terhadap pecandu Narkotika dan korban penyalahgunaan Narkotika tersangka dan atau narapidana sebagai penyalahgunaan Narkotika dibentuk Team Asesmen Terpadu.

2. Tim Asesmen Terpadu yang dimaksud dalam ayat (1) diusulkan oleh masing masing pimpinan instansi terkait di tingkat Nasional, Provinsi dan Kab/Kota dan di tetapkan oleh Kepala Badan Narkotika Nasional Kab/Kota.

3. Team Asesmen Terpadu terdiri dari :

a. Tim Dokter yang meliputi Dokter dan Psikolog

b. Tim Hukum terdiri dari unsur Polri, BNN, Kejaksaan dan Kemenkumham

4. Tim Hukum sebagaiman Pasal (3) huruf b khusus untuk penanganann tersangka anak melibatkan Balai Permasyarakatan. Pasal 9 :

1. Tim Asesmen Terpadu mempunyai tugas untuk melaksanakan:

a. Analisis terhadap seseorang yang ditangkap dan/atau tertangkap tangan dalam kaitan peredaran gelap Narkotika dan penyalahgunaan Narkotika.

b. Asesmen dan Analisis medis, psikososial, serta merekomendasikan rencana terapi

14 Wawancara dengan Kepala Bidang Pencegahan dan Pemberdayaan Masyarakat Bapak SusantO, S.H.,M.H tanggal 12 Juni 2016 dan rehabilitasi seseorang sebagaimana dimaksud dalam ayat 1 huruf a.

2. Tim Asesmen Terpadu sebagaiman dimaksud dalam pasal 8 ayat (1) mempunyai wewenang :

a. Atas permintaan penyidik untuk melakukan analisis peran seseorang yang diutangkap atau tertangkap tangan sebagai korban Penyalahgunaan Narkotika, Pecandu Narkotika atau pengedar Narkotika.

b. Menentukan kriteria tingkat keparahan pengguna Narkotika sesuai dengan jenis kandungan yang dikonsumsi, situasi dan kondisi ketika ditangkap pada tempat kejadian perkara; dan

c. Merekomendasi rencana terapi dan rehabilitasi terhadap pecandu Narkotyika dan korban penyalhgunaan Narkotika sebagaiman dimaksud pada huruf $b$.

3. Pelaksanaan Asesmen dan Analisi sebagaimana dimaksud pada ayat (1) dilakukan oleh :

a. Tim hukum bertugas melakukan analisis dalam kaitan peredaran gelap Narkotika dan Prekursor Narkotika dan penyalahgunaan Narkotika berkoordinasi dengan penyidik yang menangani perkara.

b. Tim dokter bertugas melakukan Asesmen dan Analisis medis, psikososisal serta merekomendasi rencana terapi dan rehabilitasi penyalahgunaan Narkotika. Pasal 10

15. Hasil Asesmen dan analisis sebagaimana dimaksudkan dalam pasal 9 digunakan sebagaiman bahan pertimbvangan Asesmen Terpadu dalam mengambil keputusan terhadap permohonan.

16. Hasil Aasesmen dan analisis sebagaiman dimaksudkan pada ayat (1) bersifat Rahasia sesuai dengan ketentuan peraturan perundang-undangan.

Pemeriksaan dengan dasar Undang Undang No 35 Tahun 2009 Tentang Narkotika juga didukung dengan adanya SEMA ( Serat Edaran Mahkamah Agung ) No. 04 Tahun 2010 Tentang Penempatan Penyalahgunaan, Korban Penyalahgunaan dan Pecandu Narkotika Kedalam Lembaga Rehabilitasi Medis dan 
Rehabilitasi Sosial. ${ }^{15}$ Isi dari SEMA No.

04 Tahun 2010 adalah sebagai berikut

1. Bahwa dengan telah di terbitkannya Udang-Undang Republik Indonesia Nomor 35 Tahun 2009 tanggal 12 Otober 2009 Tentang Narkotika, maka dianggap perlu untuk mengadakan revisi terhadap Surat Edaran Mahkmah Agung RI Nomor : 07 Tahun 2009 tanggal 17 Maret 2009 tentang Menempatkan Pemakai Narkotika ke Dalam Panti Terapi dan Rehabilitasi.

2. Bahwa penerapan pemidanaan sebagaiman dimaksud dalam pasal 103 huruf a dan b Undang-Undnag Republik Indonesia Nomor 25 Tahun 2009 Tentang Narkotika hanya dapat dijatuhkan pada klasifikasi tindak pidana sebagai berikut

a. Terdakwa pada saat ditangkap oleh penyidik Polri dan penyidik BNN dalam kondisi tertangkap tangan :

b. Pada saat tertangkap tangan sesuai butir a diatas ditemukan barang bukti pemakaian 1 (satu) hari dengan perincian antara lain sebagai berikut :

1) Kelompok metamphetamine (shabu) : 1 gram

2) Kelompok MDMA (ekstasi) :2,4gram $=8$ butir

3) Kelompok Heroin : 1,8 gram

4) Kelompok Kokain : 1,8 gram

5) Kelompok ganja : 5 gram

6) Daun Koka : 5 gram

7) Meskalin : 5 gram

8) Kelompok psilosybin 3 gram

9) KelompokLSD(d-lysergicaciddiethylamide : 2 gram

10) Krlompok PCP (Phencyclidine) : 3 gram

15 Wawancara dengan Kepala Bidang Pencegahan dan Pemberdayaan Masyarakat Bapak SusantO, S.H.,M.H tanggal 12 Juni 2016
11) Kelompok Fentanil 1 gram

12) Kelompok Metadon 0,5 gram

13) Kelompok Morfin : 1,8 gram

14) Kelompok Petidin : 0,9 gram

15) Kelompok Kodein : 72 gram

16) Kelompok Bufrenorfin $32 \mathrm{mg}$

c. Surat uji Laboratorium positifmenggunakan Narkotika Bedasarkan permintaan penyidik.

d. Perlu Surat Keterangan dari dokter jiwa/ psikiater pemerintah yang ditunjuk oleh hakim

e. Tindak terdapat bukti bahwa yang bersangkutan terlibat dalam peredaran gelap Narkotika.

3. Dalam hal Hakim menjatuhkan pemidanaan berupa perintah untuk dilaksanakan tindakan hukum berupa rehabilitasi atas dari Terdakwa, Majelis Hakim harus menunjukan secara tegas dan jelas tempat rehabilitasi yang terdekat dalam amar putusannya. Tempat-tempat Rehabilitasi yang dimaksud adalah:

a. Lembaga rehabilitasi medis dan sosial yang dikelola dan atau dibina dan diawasi oleh Badan Narkotika Nasional.

b. Rumah Sakit Ketergantungan Obat (RSKO) Cibubur, Jakarta.

c. Rumah Sakit Jiwa di seluruh Indonesia (Depkes RI).

d. Panti Rehabilitasi Departemen Sosial RI dan Unit Pelaksana Teknis Daerah (UPTD).

e. Tempat-tempat rujukan lembaga rehabilitasi yang diselenggarakan oleh masyarakat yang mendapat akreditasi dari Departemen Kesehatan atau Departemen Sosial (dengan biaya sendiri).

4. Untuk menjatuhkan lamanya proses rehabilitasi, Hakim harus dengan sungguhsungguh mempertimbangkan kondisi/taraf kecanduaan terdakwa, sehingga wajib diperlukan adanya keterangan ahli dan 
sebagai standardalam proses terapi dan rehabilitasi adalah sebagai berikut :

a. Program Detoksisikasi dan Stabilisasi : Lamannya 1 (satu) bulan.

b. Program Primer : Lamanya 6 (enam) bulan.

c. Program Re-Entry : Lamanya 6 (enam) bulan.

5. Dengan diterbitkannya surat edaran ini, maka Surat Edaran Mahkamah Agung Nomor : 07 Tahun 2009 tanggal 17 Maret 2009 perihal yang sama, dinytakan tidak berlaku lagi.

Adanya SEMA No. 04 Tahun 2004 semakin memperjelas perbedaan antara korban penyalahgunaan dan pecandu penyalahgunaan narkotika. Untuk proses rehabilitasinyapun juga sdh di tentukan dimana korban penyalahgunaan dapat melakukan rehabilitasi di tempat yang sudah di tunjuk oleh pihak yang berwenang. ${ }^{16}$

2. Hambatan-hambatan dalam Pemeriksaan Terhadap Pelaku Penyalahgunaan Narkotika Dengan Sistem Rehabilitasi Di BNP Jawa Tengah.

1. Saat tertangkap tangan kondisi si pelaku dalam keadaan pengaruh obat atau narkotika sehingga menghambat waktu penyidikan.

Pengaruh obat obatan atau narkotika sangat berbahaya bagi tubuh. Dampak yang di timbulkan beraneka ragam mulai dari depresi, berhalusinasi, sampai berkhayal hal yang menurutnya si pengguna atau pecandu narkotika menjadi tenang, aman, dan nyaman.

penyalahgunaan narkotiba yang dalam pengaruh obat-obatan atau narkotika sangatlah susah untuk dimintai keterangan atau menceritakan kejadian yg dia lakukan.

Pelaku masih dalam pengaruh obat dan sering berkhayal atau berhalusinasi

16 Wawancara dengan Staf Bagian TU Pencegahan dan Pemberdayaan Masyarakat Bapak Samsul Maakarif tanggal 12 Juni 2016 bahwa dia sedang melakukan hal sesuatu yang membuatnya tersenyum sendiri bahkan sering juga merasa depresi dan berdiam diri saat dilakukannya pemeriksaan. Dalam keadaan seperti inilah yang menghambat dalam melakukan proses pemeriksaan yang sedangkan kondisi si pelaku dalam pengaruh obat atau pengaruh narkotika.

2. Susah untuk mengatakan kebenaran saat dilakukan pemeriksaan (Plinplan)

Pengaruh narkotika sangat berpengaruh penting terhadap kerja syaraf otak. Pengaruh seperti ini akan menimbulkan si pelaku penyalahgunaan narkotika akan berkata-kata kalimat yang susah dipahami kebenaran, karena dalam kondisi seperti ini si pelaku penyalahgunaan merasa dirinya berhalusinasi jadi setiap kata-kata yang dia ucapkan akan berbeda2 setiap pertanyaan yang ditanyakan ke si pelaku tersebut. ${ }^{17}$

Selain itu ada juga keadaan si pelaku yang mengatakan katakan yang tidak jelas seperti dia sedang berbicara tp tidak bs di mengerti. Keadaan yang seperti ini akan menimbulkan seolah-olah pelaku penyahgunaan narkotika ini memiliki dunianya sendiri Sebagai contoh adalah sebagai berikut :

Saat melakukan pemeriksaan terhadap pelaku penyalahgunaan narkotika oleh BNN atau Polisi dan saat menanyakan sebuah pertanyaan maka si pelaku penyalahgunaan mengatakan A pada saat itu, tapi lain hari saat BNN atau polisi melakukan pemeriksaan lagi si pelaku penyalahgunaan narkotika mengatakan $\mathrm{B}$, begitu seterusnya apabila si pelaku masih dalam pengaruh narkotika.

Dari contoh tersebut akan susah

17 Wawancara dengan Staf Bagian TU Pencegahan dan pemberdayaan Masyarakat Bapak Samsul Maakarif 
untuk mendapatkan kebenaran dari kejadian yang telah terjadi.

3. Terbatasnya sarana dan prasarana rehabilitasi bagi pecandu narkotika.

Pelaku penyalahgunaan narkotika semakin banyak, pertahunnya semakin banyak para korban penyalahgunaan dan diantaranya banyak membutuhkan rehabilitasi bagi para pecandu. ${ }^{18}$

Keterbatasan sarana yang ada masih minim untuk melakukan pengobatan secara medis, khususnya tempat yang di gunakan untuk rehabilitasi masihlah terbatas, dan para ahli medis sangatlah minim sehingga penanganan korban sedikit terhambat sedangkan korban narkotika semakin bertambah.

Selain keterbatasan sarana juga keterbatasan prasarana yaitu minimnya para pelapor penyalahgunaan narkotika baik itu pengguna atau tidak pengguna yang anggota keluarganya menjadi pengguna bahkan pengedar narkotika. Padahal apabila ada anggota keluarga yang bisa melapor itu akan membantu BNN. ${ }^{19}$

Keterbatasan sarana dan prasarana inilah yang menghambat pemeriksaan terhadap pelaku penyalahgunaan narkotik.

\section{PENUTUP}

\section{Kesimpulan}

Berdasarkan hasil penelitian yang telah dilakukan, penulis menarik kesimpulan bahwa: 1. Pelaksanaan pemeriksaan terhadap

18 Wawancara dengan Kepala Bidang Pencegahan dan Pemberdayaan Masyarakat Bapak SusantO, S.H.,M.H tanggal 12 Juni 2016

19 Wawancara dengan Staf Bagian TU Pencegahan dan Pemberdayaan Masyarakat Bapak Samsul Maakarif tanggal 12 Juni 2016 penyalahgunaan narkotika dengan sistem rehabilitasi di BNP Jawa Tengah mengacu pada Undang-Undang No. 35 Tahun 2009 Tentang narkotika pasal 54 yang membahas mengenai rehabilitasi. Proses pemeriksaan dengan rehabilitasi tersebut selain berdasarkan UndangUndang No. 35 Tahun 2009 Tentang Narkotika tersebut juga diperluas dengan adanya SEMA (Surat Edaran Mahkamah Agung) No 04 Tahun 2014 Tentang Penempatan Penyalahgunaan, Korban Penyalahgunaan dan Pecandu Narkotika Ke dalam Lembaga Rehabilitasi Medis Dan Rehabilitasi Sosial serta PERBER (Peraturan Bersama) No. 01 Tahun 2014 Tentang Penanganan Pecandu Narkotika dan Korban Penyalahguna Narkotika ke dalam Lembaga Rehabilitas.

2. Berdasarkan SEMA No. 04 Tahun 2014 Tentang Penempatan Penyalahgunaan, Korban Penyalahgunaan dan Pecandu Narkotika ke Dalam Lembaga Rehabilitasi Medis Dan Rehabilitasi Sosial membedakan antara ciri-ciri pelaku penyalahgunaan narkotika dengan Korban penyalahgunaan narkotika dengan adanya kelompok obatobatan yang lebih detail dan terperinci memurut kelompoknya. Kelompok obatobatan inilah yang dijadikan pedoman dalam menentukan si pelaku tergolong dalam pelaku penyalahguna atau korban penyalahguna. Sedangkan untuk PERBER (Peraturan Bersama) No. 01 Tahun 2014 Tentang Penanganan Pecandu Narkotika dan Korban Penyalahguna Narkotika ke dalam Lembaga Rehabilitas lebih menjelaskan mengenai Team Asesmen Terpadu. Team Asesmen Terpadu adalah tim yang terdiri dari Tim Dokter dan Tim Hukum yang ditetapkan oleh pimpinan satuan kerja setempat berdasarkan surat keputusan Kepala Badan Narkotika Nasional, Badan Narkotika Nasional Provinsi, Badan Narkotika Nasional Kab/Kota.

3. Hambatan dalalm Pemeriksaan Terhadap Pelaku Penyalahguna Narkotika Dengan Sistem Rehabilitasi Di BNP Jawa Tengah 
1. Saat tertangkap tangan kondisi si pelaku dalam keadaan pengaruh obat atau narkotika sehingga menghambat waktu pemeriksaan.

2. Kesulitan dalam memberikan keterangan yang benar saat dilakukan pemeriksaan (Plinplan).

3. Terbatasnya sarana dan prasarana rehabilitasi bagi pecandu narkotika

Cara menghadapi hambatan tersebut dengan cara agar penyidik lebih sabar dalam melakukan pemeriksaan terhadap pelaku penyalahgunaan narkotika, karena dalam pengaruh narkotika si pelaku meiliki halusinasi sendiri, memeliki dunianya sendiri dan adapula yang terdiam diri. Selain itu pentingnya kerjasama dengan instansi lain untuk mempercepat proses pemeriksaan kasus narkotika dan membuka akses bagi masyarakat yang ingin melapor atau ada salah satu anggota keluarganya yang menjadi korban penyalahgunaan bs melapor melalui telepon, sms, atau bisa datang langsung ke BNP Jawa Tengah atau bisa datang ke Kantor Polisi dan idenditas si pelapor akan tersebut akan dirahasiakan

\section{Saran}

1. Agar pelaku penyalahgunaan narkotika di hukum mati karena narkotika dapat membahayakan keselamatan orang lain

2. Lebih di tingkatkan lagi dalam penangkapan korban penyalahgunaan narkotika.

3. Agar dalam melakukan pemeriksaan terhadap korban penyalahgunaan narkotika lebih sabar dan berhatihati karena korban dalam pengaruh narkotika.

\section{DAFTAR PUSTAKA}

\section{- Buku-Buku:}

Abdulsyani, 1987, Sosiologi Kriminalitas, CV.Remadja Karya, Bandung

Ahmad Hanafi, 1967, Asas-Asas Hukum Pidana I Islam, Bulan Bintang, Jakarta;

Mahmutarom HR, 2010, Rekonstruksi Konsep Keadilan (Studi Tentang Perlindungan Korban

Tindak Pidana Terhadap Nyawa Menurut Hukum Islam, Konstruksi Masyarakat dan Instrumen Internasional), Universitas Diponegoro, Semarang;

Ronny Hanintijo Soemitro, 1990, Metode Penelitian Hukum dan Jurimetri, Ghalia Indonesia, Jakarta;

Soerjono Soekanto, 2004, Faktor-faktor Yang Mempengaruhi Penegakan Hukum, PT RajaGrafindo, Ctk.keempat, Jakarta;

\section{- Peraturan perundang-undangan:}

Undang-Undang Nomor 21 Tahun 2007 Tentang Pemberantasan Tindak Pidana Perdagangan Orang.

- Makalah:

Nur Rochaeti,. "Perlindungan Hukum Bagi Perempuan dan Anak Korban Perdagangan orang (trafficking) Di Indonesia", Diklat Penanganan Perkara Perdagangan orang Tahun 2008, Kejaksaan Tinggi Jawa Tengah;

Laporan Penelitian LRC-KJHAM Tahun 2012-2013 Tentang Trafficking, Semarang; 